\title{
A Model To Determine Capital Needs For Efficient Boer Goat Farming
}

Merwe Oberholzer, North-West University, South Africa

Pieter W. Buys, North-West University, South Africa

Wilbrie Fourie, Tacktech (Pty) Ltd, South Africa

\begin{abstract}
The purpose of this study is to determine the optimal capital needs to establish a Boer goat farm. A study was performed to simulate the financial performance of 55 scenarios, with varying farm sizes and varying levels of capital employed. These results formed the basis to create a data envelopment analysis model, where farm sizes and capital employed are used as input variables versus eight financial performance indicators as output variables. The study found that the scenarios are technically efficient, but only 23 of the 55 scenarios are fully scale efficient, with six scenarios operating on a scale that is too small and 26 operating on a scale that is too large, which implies that 32 of the scenarios did not achieve economies of scale. Furthermore, nine of the ten farm sizes used are not scale efficient when using 100\% of their capital needs. The study therefore concludes that the financial success of starting a South African (SA) Boer goat farm is locked up in the natural growth of the herd, with the practical implication that aspirating SA Boer goat farmers will be most efficient when using a limited amount of capital and not immediately stock the farm at the maximum level of animals, but to stock it only partly and wait for the gain in the growth of the herd.
\end{abstract}

Keywords: South African Boer Goat; Capital; Data Envelopment Analysis; Scale Efficiency; Technical Efficiency

\section{INTRODUCTION}

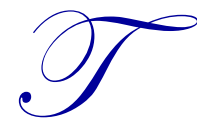

his article formed part of a greater investigation into the viability of South African (SA) Boer goat farming relative to other red meat products, and builds on an actual case study, of which the results are used here to evaluate the capital needs for efficient SA Boer goat farming. The actual case study's information and assumptions are available in the appendix. In this article, a model is developed to determine the relative efficiency of how inputs, farm size, and capital employed are converted into a number of financial performance indicators of SA Boer goat farming. A case study was developed to simulate the financial performance of 55 scenarios, each with varying farm sizes and amounts of capital employed. The South African Boer goat-, South African Savanna- and the South African Kalahari Red specimen are home-bred South African goat species, and are known under the collective noun of 'the SA Boer goat' (SA Boer Goat Breeders Association, 2011).

The need for investigating SA Boer goat farming is boosted by the fact that it can provide high-quality, low-fat red meat products, with the South African Boer goat being considered as the best goat species in the world (Malan, 2000). In further support hereof, Mahgoub, Kadim, and Lu (2012a) state that, of all the specialized meat goat breeds in the world, 'the South African Boer goat is the most notable.' The importance of this study is that the results can assist farmers and financial consultants in their decision-making processes regarding the capital requirements in order to achieve the optimal financial performance when establishing an SA Boer goat farm. The value hereof must be evaluated against the background that there is, unlike other livestock species in South Africa, currently no readily available market indicators for SA Boer goats (Landbouweekblad, 2013). This lack of information leads to price uncertainties and therefore difficulties in estimating the financial and capital needs of operating an SA Boer goat farm. 
Many prior researchers have investigated the viability of SA Boer goat farming, including Casey and Van Niekerk (1988), who concluded that the adaptability of any farm animal, within the context of the climate and production techniques, is the most important element to maximize return on investment. In this regard, Mason (1988) found that the production is a key indicator of the environmental adaptability of an animal, with SA Boer goats having a reputation for high fertility. In terms of the suitability of the species in the South African environment, Schoeman, Cloete, and Olivier (2010) mention that approximately $80 \%$ of South Africa is unsuitable for conventional crop production (such as corn and wheat) and that a large part of the country is also not suitable for large stock (e.g. cattle) grazing; consequently, such agricultural land can only be utilized for raising small stock species. Within this context, SA Boer goats are able to utilize marginal agricultural land unsuitable for other livestock species, while at the same time providing a cost efficient source of animal protein for human consumption (Mahgoub et al., 2012b).

Against the backdrop of a healthier lifestyle, the SA Boer goat may be considered as superior to other typical red meat products such as pork, beef, and lamb, because of its affordability and better muscle-fat-bone ratio (Mahgoub, Kadim, \& Webb, 2012b; Botha, 1999). This is supported by Malan (2000) who found that there is prospective growth potential for SA Boer goat meat as a result of the healthier lifestyle that requires meat with a lower fat content. Gouws (2002), who investigated the demand for SA Boer goats and its market growth, found that the market has grown annually by eight percent from 1990 to 2000 .

Finally, Midgley (2007) determined that even though the number of animals sold has a significant influence on the profitability of a meat farm, the quality of the animals also has an important role therein. Therefore, according to Schoeman et al. (2010), small stock species, especially SA Boer goats, will have an integral part in the future South African economy and agricultural sector.

\section{RESEARCH PROBLEM, OBJECTIVES AND METHODOLOGY}

The above-mentioned studies revealed much information about the physical, operational and financial aspects of SA Boer goat farming, but little about the capital needs thereof. To address this knowledge gap, this study aimed to determine the optimal capital needs of establishing a SA Boer goat farm. The central argument of this study is that a farmer is in possession of a specific farm, and needs to understand the capital requirements to operate the farm most efficiently.

In order to fulfill this purpose, a study was designed to simulate 55 different scenarios to calculate the financial performance in instances of varying farm sizes and levels of capital employed. These results formed the basis to create a data envelopment analysis (DEA) model, where different farm sizes and capital employed levels are used as input variable versus eight financial performance indicators as output variables. DEA, as an efficiency measurement technique, lends itself to aggregate organizational performances into a single measure where multiple inputs and multiple outputs are used (Coelli, Rao, O'Donnell, \& Battese, 2005). The relative efficiency of the 55 scenarios is investigated in order to empirically determine the technical and scale efficiencies of the different scenarios.

The remainder of the article is organized as follows: The next section provides an explanation of the theoretical context of the eight financial performance measures used in developing the model in this study, followed by a discussion of DEA as an evaluation tool to measure efficiency, the method employed in the study, the reporting of the empirical results, after which the concluding discussion and research limitations are provided.

\section{MEASURE OF FINANCIAL PERFORMANCE}

This section discusses the eight management accounting techniques that have been identified to evaluate the performance, capital investment evaluation and risk of SA Boer goat farming. According to Hawawini and Viallet (2011), relevant cashflow is just the change in the overall cash position that could be attributed to the investment decision. Within the context of this article, therefore, cognizance should be taken of the fact that the different types of meat producers have similar expenses; for example, land, cell phone and vehicle expenses that should not automatically be taken into account in the investment decision because it is not unique to the type of 
farming. For the purpose of this study, therefore, a contribution statement that only takes relevant income and expenses into account was used. The relevant contribution is taken as the difference between the relevant income, such as sales income from weaning and culling, and relevant expenses, such as dosing, mineral supplements, and labor. As it is viewed as an investment decision, with returns over a reasonable period of time, the results are calculated for a period of five years.

\section{Performance Measurement}

The following performance measurement techniques have been selected for the short-term financial performance evaluation, namely i) return on investment, ii) contribution per hectare (which is a profitability indicator), and iii) asset turnover (which is an asset management indicator) (Lovemore \& Brümmer, 2005).

- $\quad$ Return on Investment: The equation for this calculation is the operating profit divided by invested capital (Correia, Flynn, Uliana, \& Wormald, 2010; Hawawini \& Viallet, 2011). For purposes of this study, the operating profit has been replaced by the relevant contribution, while the invested capital component consists of the purchase cost of the herd and other relevant capital expenditures such as feeding troughs, fencing, and stock handling facilities. The total relevant contribution over five years will be shared by the capital initially applied.

- $\quad$ Contribution per Hectare: The purpose of this ratio is to determine output that the farmer obtains from the land input, by dividing the relevant contribution by the farm size. It is therefore indicative of the profitability relative to farm size. The total contribution per hectare has been calculated over five years.

- $\quad$ Asset Turnover: This is determined by dividing the total turnover of an entity by its total assets in order to evaluate the effective usage of the assets (Hawawini \& Viallet, 2011; Correia et al., 2010). In this study, the total assets have been replaced with capital invested (as defined above) and output is the same as sales revenue above. The total relevant income over five years has been divided by the initial capital implemented.

\section{Capital Investment Evaluation}

The following capital investment techniques have been selected to evaluate the long-term financial performance (Correia et al., 2010):

- $\quad$ Payback Period: The original equation for determining the payback period is capital investment divided by annual cashflow (Correia et al., 2010). For purposes of this study, the latter is replaced by the annual relevant contribution.

- $\quad$ Accounting Rate of Return: The accounting rate of return is calculated by dividing average annual profit by the average investment (Hawawini \& Viallet, 2011). For the purpose of the study, the profit has been replaced by the relevant contribution. The total relevant contribution over five years has been divided by the average capital implemented.

- $\quad$ Net Present Value: The net present value is typically calculated by discounting the annual relevant contribution and capital investments over a number of years to the present value. It has been determined over a period of five years and the rate used is an inflation rate of four percent plus six percent returns during a period of relatively low inflation, as a widely accepted standard (Correia et al., 2010).

\section{Risk}

Two techniques to evaluate the applicable risk have been identified, namely:

- Sensitivity: The sensitivity analysis measures how a project's outcomes might be expected to change should any of the input variables change (Correia et al., 2010). For the purpose of this study, the sales revenue was adjusted downward by one percent to measure the change in the relevant contribution.

- $\quad$ Break-Even Point: According to Correia et al. (2010), the break-even point is indicated by the number of units a specific project has to sell in order to reach a zero net present value when considering the cost 
inflows and outflows. The objective of this study is to determine what percentage of the total income may decrease over five years to provide a relevant contribution of zero.

\section{DEA AS A MEASURE OF EFFICIENCY}

Data Envelopment Analysis (DEA) is a method for relating all the input and output data about an entity into a singular measure of productive efficiency, which lies between zero (i.e. the entity is totally inefficient) and one (i.e. the entity is fully efficient) (Oberholzer, 2012). The fundamental assumption of DEA is that if a producer, called a decision-making unit (DMU), is capable of producing $Y(\mathrm{~A})$ units of output with $X(\mathrm{~A})$ inputs, then other producers should also be able to do the same if they were operating efficiently. The fundamental objective of the DEA modeling exercise is therefore to find the 'best' virtual producer for each real producer and then to compare such real producer to the best virtual producer in order to determine its efficiency. The best virtual producer is found by means of linear programming (Anderson, 1996). Analyzing the efficiency of a number of DMUs requires a formulation of a linear programming problem for each DMU. DEA is a non-parametric linear programming technique that measures the relative efficiency of a comparative ratio of outputs to inputs for a particular DMU (Ray, 2004). In other words, it compares the efficiency of how the same multiple inputs and the same multiple outputs are converted by a DMU, relative to other competing DMUs in the sample (Liu \& Wang, 2009; Min, Min, Joo, \& Kim, 2009). DEA effectively estimates the frontier by finding a set of linear segments that envelop the observed data. DEA can determine efficiencies from an input-orientated (input minimization) or output-orientated (output maximization) point of view (Coelli et al., 2005). Furthermore, it provides the ability to identify inefficient DMUs and potential improvement areas for them, either by reducing inputs or increasing outputs, as well as highlighting efficient DMUs that could be used as benchmarks by less efficient DMUs (Liu \& Wang, 2009; Avkiran, 1999).

The focus of this study is on technical and scale efficiency (TE and SE, respectively), where the different scenarios in the study represent the comparative DMUs. Technical efficiency is an indication of how well inputs are converted into outputs, while scale efficiency estimates whether a DMU operates on a scale that maximizes productivity (Buys, Oberholzer, \& Prinsloo, 2011; Murthy, Sudha, Hegde, \& Dakshinamoothy, 2009). According to Avkiran (1999), analysts typically choose between using constant return to scale (CRS) or variable return to scale (VRS). The CRS implies a proportionate rise in outputs when inputs are increased, or in other words, a scenario's efficiency is not influenced by the scale of its operations (Avkiran, 1999). On the other hand, Avkiran (1999) states that VRS implies a disproportionate rise or fall in outputs when inputs are increased, or in other words, if a scenario grows in size, its efficiency will not remain constant, but it will either rise or fall. Using CRS, a scenario is automatically considered fully scale efficient, while using the VRS approach the degree of scale efficiency should be estimated, i.e. where a scenario is too small in its scale operations, which falls within the increasing return to scale (irs) part of the production function, and a scenario is too large if it falls within the decreasing return to scale (drs) part of the production function. These inefficient scenarios can be improved upon by keeping the same input mix, but changing the size of operations (Coelli et al., 2005; Theunissen, 2012).

To illustrate, Figure 1 assumes that the observed data consists of a single-input, single-output with five DMUs, namely A, B, C, D, and $\mathrm{H} .0 \mathrm{BC}$ is the CRS frontier. A, D, and $\mathrm{H}$ are not on the efficiency frontier and therefore they are considered non-efficient. $\mathrm{H}$, for example, should move from an input-orientated view, horizontally to point $H$ " to become fully efficient. The less restricted VRC frontier is indicated by ABCD. Under this approach, $\mathrm{H}$ only needs to move horizontally to point $\mathrm{H}^{\prime}$. To summarize, $\mathrm{TE}_{\mathrm{VRS}}$ implying that $\mathrm{H}^{\prime} \mathrm{H}$ is the technical inefficiency distance. $\mathrm{TE}_{\mathrm{CRS}}$ indicates the overall improvement that is possible, namely $\mathrm{H}$ " $\mathrm{H}$. $\mathrm{SE}=\mathrm{TE}_{\mathrm{CRS}} / \mathrm{TE}_{\mathrm{VRS}}$, means that the distance H'H' represents the scale inefficiency, which should be improved upon by keeping the same input mix, but changing the size of operations (Zhu, 2009; Coelli et al., 2005). 


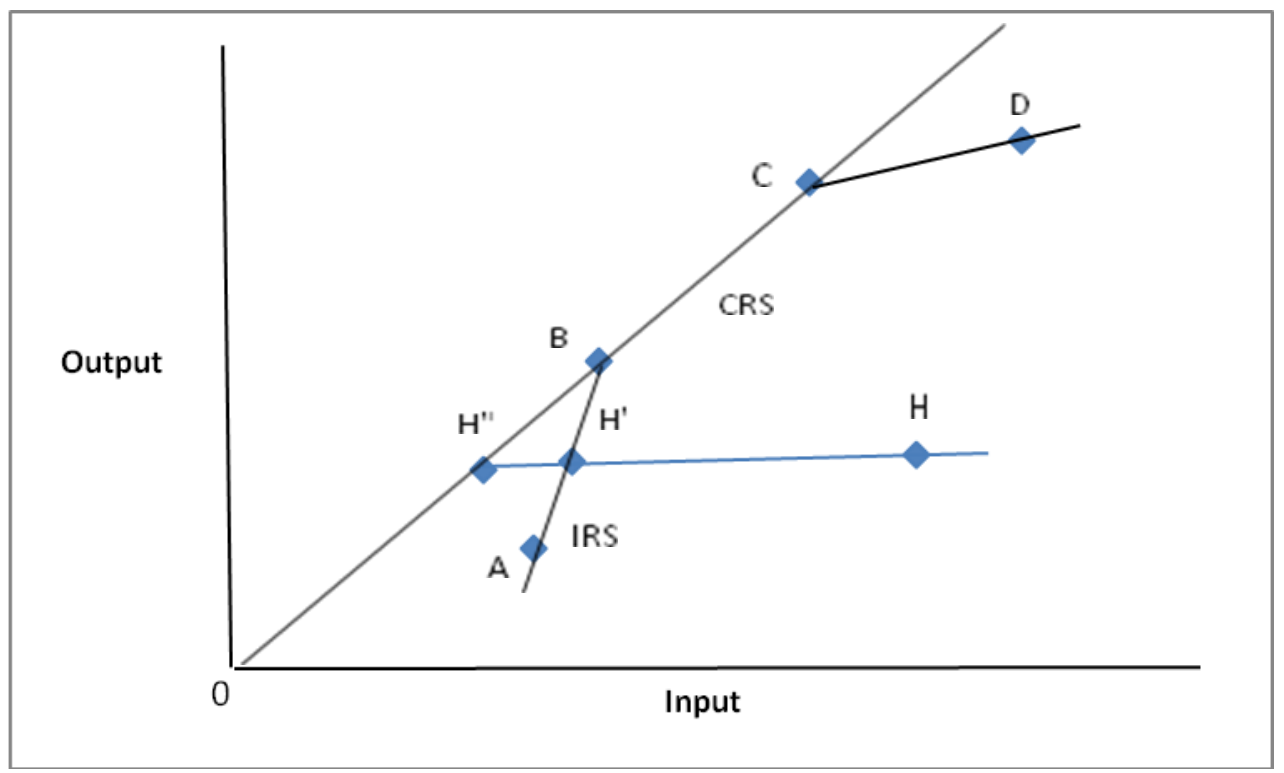

Figure 1: CRS and VRS Efficiency Frontiers

Source: Adapted from Zhu (2009)

As stated earlier, the purpose of this study is to determine the optimal capital needs of establishing an SA Boer goat farm. Therefore, DEA can assist from an input-orientated view, whether or not a scenario with unique input values of farm size and capital employed operates on the efficiency frontier. Using the VRS and CRS approaches, technical and scale efficiency can be determined, respectively. A model is needed to show which of the unique scenarios are the most efficient to convert the input variables into financial gains. Therefore, from an inputorientated view, the open question is: How much capital should be employed for a given farm size? To answer the question, the following DEA equation is used to create the model (Zhu, 2009):

$\min \theta-\varepsilon\left(\sum_{i=1}^{m} s_{i}^{-}+\sum_{r=1}^{s} s_{r}^{+}\right)$

subject to

$\sum_{j=1}^{n} \lambda_{j} \chi_{i j}+s_{i}^{-}=\theta \chi_{i o} \quad i=1,2, \ldots ., m$

$\sum_{j=1}^{n} \lambda_{j} \gamma_{r i}-s_{r}^{+}=\gamma_{r o} \quad r=1,2, \ldots ., s ;$

CRS $\quad \lambda_{j} \geq 0 \quad j=1,2, \ldots ., n$.

$\operatorname{VRS}:$ Add $\sum_{j=1}^{n} \lambda_{j}=1$

The above input-orientated formula calculates input minimization (where $\theta$ indicates the efficiency score). Each observation, $D M U_{j}(j=1, \ldots, n)$, uses $m$ inputs $X_{i j}(\mathrm{i}=1,2, \ldots, m)$ to produce $s$ outputs $\mathrm{Y}_{\mathrm{rj}}(r=1,2, \ldots, s)$, where $D M U_{o}$ represents one of the $n D M U$ s under evaluation, and $X_{i o}$ and $Y_{r o}$ are the $i$ th input and $r$ th output for $D M U_{o}$, respectively. In order to take any slack into consideration, the inclusion of the non-Archimedean $\varepsilon$ effectively allows the minimization over $\theta$ to pre-empt the optimization involving the slacks, $s_{i}{ }^{-}$and $s_{r}{ }^{+}$. (For a more detailed discussion on the DEA methodology, see Ray, 2004; Zhu, 2009; Coelli et al., 2005; Theunissen, 2012) 


\section{METHOD}

\section{Data}

The study (Appendix) formed the basis to provide data for the rest of the study. To ensure sufficient discrimination, a wide range of 10 farm sizes were randomly chosen, i.e. the smallest of 100 hectares, increasing with intervals of 100 hectares, and the largest of 1,000 hectares. To ensure a wide range of capital available levels, the maximum capital needs (100\%) for each farm size were calculated, i.e. to pay for improvement of fences, stock handling facilities and to buy the maximum number of goats according to the bearing power of the farm. To ensure that no scenario has more than $100 \%$ of its capital available, for each farm size, the $100 \%$ capital needs level is used as well as the $100 \%$ capital needs of all the smaller farm sizes. For example, a farm size of 1,000 hectares has ten scenarios, namely $100 \%$ of its capital needs plus the $100 \%$ capital needs of each of the nine remaining smaller farm sizes. The farm size of 900 hectares has nine scenarios, $100 \%$ of its own needs and $100 \%$ of the eight remaining smaller farm sizes, etc. The maximum capital needs range from R223,556 for a 100 hectare farm to R1,817,541 for a 1,000 hectare farm $(\mathrm{R}=$ rand or ZAR, the South African currency). Note that the capital needs to exclude working capital, because, once the optimum capital is determined for a farm size, the number of animals to be purchased is known that will determine the working capital needs.

From these data, eight financial performance indicators were also calculated for the 55 different farm size and capital employed scenarios. Farm size plus capital employed plus the eight financial performance indicators provide in total ten variables, multiplied by the 55 scenarios, and the study applied in total 550 data points.

\section{Variables and DEA Model}

The two input variables in the study are the ten different farm sizes and ten different levels of capital employed. The output variables are indicated in Table 1 below, including the descriptive statistics for each variable. For a scenario to be relatively efficient, it should have low inputs and high outputs. For all these financial performance indicators, except the payback period and sensitivity analysis, a higher value implies a higher performance, where the payback period and the sensitivity analysis imply a higher value a lower performance. Therefore, these two measures are indicated in terms of their reciprocal values.

Table 1: Descriptive Statistics of Output Variables

\begin{tabular}{|l|cccccccc|}
\hline & ROI & $\begin{array}{c}\text { Contribution } \\
\text { /Hectare }\end{array}$ & $\begin{array}{c}\text { Asset } \\
\text { Turn Over }\end{array}$ & 1/Payback & ARR & NPV & 1/Sensitivity & Breakeven \\
\hline Mean & 2.40 & 2644 & 3.77 & 0.36 & 4.81 & 510907 & 63.93 & 0.64 \\
Median & 2.39 & 2963 & 3.66 & 0.38 & 4.77 & 550127 & 66.15 & 0.66 \\
Standard Deviation & 0.45 & 1022 & 0.71 & 0.06 & 0.90 & 291877 & 6.03 & 0.06 \\
Minimum & 1.49 & 334 & 2.42 & 0.24 & 2.99 & 10905 & 46.94 & 0.47 \\
Maximum & 3.16 & 3720 & 5.11 & 0.42 & 6.32 & 978951 & 68.72 & 0.69 \\
\hline
\end{tabular}

In the DEA model, the input and output variables are:

$$
\begin{array}{ll}
\text { Input: } & \mathrm{x}_{1}=\text { farm size (in terms of hectare) } \\
\text { Output: } & \mathrm{x}_{2}=\text { capital available (in terms of ZAR) } \\
& \mathrm{y}_{1}=\text { return on investment }(\mathrm{ROI}) \\
& \mathrm{y}_{2}=\text { contribution per hectare } \\
\mathrm{y}_{3}=\text { asset turnover } \\
\mathrm{y}_{4}=1 / \text { payback period } \\
\mathrm{y}_{5}=\text { accounting rate of return }(\mathrm{ARR}) \\
\mathrm{y}_{6}=\text { net present value (NPV) } \\
\mathrm{y}_{7}=1 / \text { sensitivity } \\
\mathrm{y}_{8}=\text { break-even }
\end{array}
$$

The software, purposefully developed by Zhu (2009), was used to calculate the input-orientated technical efficiency estimates to determine how efficiently each scenario converts the inputs into outputs; to detect efficient 
scenarios that can be used as a benchmark for the inefficient ones; and to set targets of how much the inefficient scenarios' inputs should decrease to become fully efficient. Furthermore, using both variable return to scale (VRS) and constant return scale (CRS), the model also provides the scale efficiency of each scenario.

\section{EMPIRICAL RESULTS}

Table 2 indicates in the second column the 55 scenarios. The number before the hyphenation indicates the farm size and the number thereafter the maximum capital needs of a specific farm size, e.g. Scenario 1 indicates the farm size is 100 hectares and the maximum capital needs of a 100 hectare farm is used, Scenario 2 indicates the farm size is 200 hectares and the maximum capital needs of a 100 hectare farm is used, etc. The third column indicates the capital amount relative to the maximum capital needs, e.g. Scenario 1's capital employed represents $100 \%$ of its maximum capital needs, Scenario 2's capital employed represents $55.5 \%$ of its maximum capital needs, etc. Column 4 indicates the $\mathrm{TE}_{\mathrm{VRS}}$ of the 55 scenarios. TE can take a value between 0 and 1 , where 1 indicates that a scenario is fully technically efficient. Only Scenario 47 is not fully technically efficient. The estimate of 0.878 implies that this scenario should reduce its inputs by $12.2 \%$ to become fully efficient like all the others. Except for this one case, these results imply that the inefficiencies are the result of the size (scale) of operations. $\mathrm{TE}_{\mathrm{CRS}}$ indicates the overall aggregated efficiency.

Since $\mathrm{SE}=\mathrm{TE}_{\mathrm{CRS}} / \mathrm{TE}_{\mathrm{VRS}}$, the $\mathrm{TE}_{\mathrm{CRS}}$ equals the SE, except Scenario 47 , because in all the other scenarios $\mathrm{TE}_{\mathrm{VRS}}=1$. Only 23 of the 55 scenarios are fully scale efficient, operating on the constant return to scale of the operation function. Six and 26 operate in the increasing return to scale and decreasing return to scale part of the operation function, respectively. In all the scenarios with a farm size of less than 400 hectares, the inefficiencies are due to a decreasing return to scale, which implies that these scenarios are too large in their scale of operations (Column 5, RTS = return to scale). For the rest of the scenarios, the same pattern is recognized, i.e. for all the farm sizes, where the maximum capital needs of a 100 hectare farm size are used, an increasing return to scale is indicated, implying that these scenarios are too small in their scale of operations. Furthermore, specific patterns can be recognized; for the farm sizes of 400 hectares and smaller, the efficient scenarios are those with the lower levels of capital. For the rest of the scenarios, the efficient scenarios are found somewhere in the middle of each farm-size group. In other words, the inefficient scenarios are those with the extreme lower as well as the extreme higher levels of capital. It is also obvious that for all farm sizes, except the 100 hectare farm, no one is fully efficient when using $100 \%$ of their own capital needs.

Although the CRS approach is based on the assumption that scenarios are able to linearly scale their inputs and outputs without changing their efficiency, its value is that it helped to arrive to the conclusion that 32 , i.e. $26+$ 6 , of the scenarios did not achieve economies of scale. To explain this, consider an example where a farm can achieve economies of scale by producing R100 within a specific period. When producing on the decreasing to scale part of the production function, they may require, for example, three times as much input only to double the outputs to R200. On the opposite side, if they are producing on an increasing return to scale part of the production function, they may, for example, require half of the inputs to produce only a quarter of the outputs, namely R25.

The last two columns in Table 2 suggest the input targets for the inefficient scenarios to enable them to become fully efficient; in other words, to operate on the efficiency frontier. These numbers indicate how much the input variables should change. For example, the farm size and the capital level of Scenario 3 should be reduced by 3.8 and $26.1 \%$, respectively.

Focusing on capital employed levels, a farm size of 200 hectares is fully efficient when using only $55.5 \%$ of its capital needs, and a 300 hectare farm is fully efficient using between 38.5 and $69.3 \%$ of its capital needs. For the rest, it is as follows: 400 hectares - between 29.5 and $53.1 \%$; 500 hectares - 43.1\%; 600 hectares - between 36.2 and $68.2 \%$; 700 hectares $-45.1 \% ; 800$ hectares - between 39.6 and $63.8 \%$; 900 hectares - between 35.4 and $67.7 \%$; and 1,000 hectares - between 31.9 and $70.9 \%$. To summarize, economies of scale are reached when employing between approximately 30 and $70 \%$ of the maximum capital needs. 
Table 2: Efficiency Estimates, Return to Scale and Targets for the 55 Scenarios

\begin{tabular}{|c|c|c|c|c|c|c|c|}
\hline \multirow[b]{2}{*}{ Scenario } & \multirow[b]{2}{*}{ Name } & \multirow{2}{*}{ Employed/Need } & \multicolumn{2}{|c|}{ Technical Efficiency } & \multirow[b]{2}{*}{ RTS } & \multicolumn{2}{|c|}{ Targets } \\
\hline & & & VRS & CRS & & Hectare & Rand \\
\hline 1 & $100-100$ & 1.000 & 1.000 & 1.000 & Constant & & \\
\hline 2 & $200-100$ & 0.555 & 1.000 & 1.000 & Constant & & \\
\hline 3 & $200-200$ & 1.000 & 1.000 & 0.963 & Decreasing & -0.038 & -0.261 \\
\hline 4 & $300-100$ & 0.385 & 1.000 & 1.000 & Constant & & \\
\hline 5 & $300-200$ & 0.693 & 1.000 & 1.000 & Constant & & \\
\hline 6 & $300-300$ & 1.000 & 1.000 & 0.952 & Decreasing & -0.051 & -0.369 \\
\hline 7 & $400-100$ & 0.295 & 1.000 & 1.000 & Constant & & \\
\hline 8 & $400-200$ & 0.531 & 1.000 & 1.000 & Constant & & \\
\hline 9 & $400-300$ & 0.766 & 1.000 & 0.991 & Decreasing & -0.009 & -0.107 \\
\hline 10 & $400-400$ & 1.000 & 1.000 & 0.946 & Decreasing & -0.057 & -0.425 \\
\hline 11 & $500-100$ & 0.239 & 1.000 & 0.951 & Increasing & -0.314 & -0.051 \\
\hline 12 & $500-200$ & 0.431 & 1.000 & 1.000 & Constant & & \\
\hline 13 & $500-300$ & 0.621 & 1.000 & 0.999 & Decreasing & -0.001 & -0.001 \\
\hline 14 & $500-400$ & 0.811 & 1.000 & 0.981 & Decreasing & -0.020 & -0.183 \\
\hline 15 & $500-500$ & 1.000 & 1.000 & 0.943 & Decreasing & -0.061 & -0.458 \\
\hline 16 & $600-100$ & 0.201 & 1.000 & 0.847 & Increasing & -1.151 & -0.180 \\
\hline 17 & $600-200$ & 0.362 & 1.000 & 1.000 & Constant & & \\
\hline 18 & $600-300$ & 0.522 & 1.000 & 1.000 & Constant & & \\
\hline 19 & $600-400$ & 0.682 & 1.000 & 1.000 & Constant & & \\
\hline 20 & $600-500$ & 0.841 & 1.000 & 0.973 & Decreasing & -0.027 & -0.238 \\
\hline 21 & $600-600$ & 1.000 & 1.000 & 0.941 & Decreasing & -0.062 & -0.447 \\
\hline 22 & $700-100$ & 0.174 & 1.000 & 0.799 & Increasing & -2.119 & -0.252 \\
\hline 23 & $700-200$ & 0.312 & 1.000 & 0.993 & Decreasing & -0.097 & -0.007 \\
\hline 24 & $700-300$ & 0.451 & 1.000 & 1.000 & Constant & & \\
\hline 25 & $700-400$ & 0.588 & 1.000 & 0.999 & Decreasing & -0.001 & -0.001 \\
\hline 26 & $700-500$ & 0.726 & 1.000 & 0.996 & Decreasing & -0.004 & -0.067 \\
\hline 27 & $700-600$ & 0.863 & 1.000 & 0.968 & Decreasing & -0.033 & -0.279 \\
\hline 28 & $700-700$ & 1.000 & 1.000 & 0.941 & Decreasing & -0.063 & -0.443 \\
\hline 29 & $800-100$ & 0.153 & 1.000 & 0.791 & Increasing & -2.633 & -0.264 \\
\hline 30 & $800-200$ & 0.275 & 1.000 & 0.957 & Decreasing & -0.316 & -0.044 \\
\hline 31 & $800-300$ & 0.396 & 1.000 & 1.000 & Constant & & \\
\hline 32 & $800-400$ & 0.517 & 1.000 & 1.000 & Constant & & \\
\hline 33 & $800-500$ & 0.638 & 1.000 & 1.000 & Constant & & \\
\hline 34 & $800-600$ & 0.759 & 1.000 & 0.989 & Decreasing & -0.011 & -0.121 \\
\hline 35 & $800-700$ & 0.880 & 1.000 & 0.965 & Decreasing & -0.037 & -0.260 \\
\hline 36 & $800-800$ & 1.000 & 1.000 & 0.941 & Decreasing & -0.063 & -0.457 \\
\hline 37 & $900-100$ & 0.136 & 1.000 & 0.784 & Increasing & -3.162 & -0.275 \\
\hline 38 & $900-200$ & 0.245 & 1.000 & 0.922 & Decreasing & -0.556 & -0.084 \\
\hline 39 & $900-300$ & 0.354 & 1.000 & 1.000 & Constant & & \\
\hline 40 & $900-400$ & 0.462 & 1.000 & 1.000 & Constant & & \\
\hline 41 & $900-500$ & 0.570 & 1.000 & 1.000 & Constant & & \\
\hline 42 & $900-600$ & 0.677 & 1.000 & 1.000 & Constant & & \\
\hline 43 & $900-700$ & 0.785 & 1.000 & 0.984 & Decreasing & -0.016 & -0.121 \\
\hline 44 & $900-800$ & 0.893 & 1.000 & 0.962 & Decreasing & -0.039 & -0.289 \\
\hline 45 & $900-900$ & 1.000 & 1.000 & 0.941 & Decreasing & -0.063 & -0.467 \\
\hline 46 & $1000-100$ & 0.123 & 1.000 & 0.778 & Increasing & -3.706 & -0.286 \\
\hline 47 & $1000-200$ & 0.222 & 0.878 & 0.829 & Decreasing & -0.969 & -0.206 \\
\hline 48 & $1000-300$ & 0.319 & 1.000 & 1.000 & Constant & & \\
\hline 49 & $1000-400$ & 0.417 & 1.000 & 1.000 & Constant & & \\
\hline 50 & $1000-500$ & 0.514 & 1.000 & 1.000 & Constant & & \\
\hline 51 & $1000-600$ & 0.612 & 1.000 & 1.000 & Constant & & \\
\hline 52 & $1000-700$ & 0.709 & 1.000 & 1.000 & Constant & & \\
\hline 53 & $1000-800$ & 0.806 & 1.000 & 0.980 & Decreasing & -0.020 & -0.154 \\
\hline 54 & $1000-900$ & 0.903 & 1.000 & 0.961 & Decreasing & -0.041 & -0.313 \\
\hline 55 & $1000-1000$ & 1.000 & 1.000 & 0.941 & Decreasing & -0.063 & -0.476 \\
\hline
\end{tabular}




\section{CONCLUDING DISCUSSION}

The purpose of the study was to determine the optimal capital needs of establishing an SA Boer goat farm. Firstly, a study was designed to simulate 55 scenarios of the financial performance for different farm sizes with different capital amounts employed. These results formed the basis to create a DEA model, where farm sizes and capital employed are used as input variable versus eight financial performance indicators as output variables. The input-orientated DEA model applied both the VRS and CRS approaches to determine the technical and scale efficiencies of the 55 scenarios.

The study found firstly that 54 of the 55 scenarios are technically efficient according to the VRS approach, implying these scenarios are all able to obtain the maximal financial performance from the input mix of farm size and capital employed. From this finding, the conclusions can be drawn that SA Boer goat farms can, given almost any combination of input mixes, convert them efficiently into financial success, but the study also found that only 23 of the 55 scenarios are fully scale efficient, where six operate on a scale that is too small and 26 operate on a scale that is too large. Therefore, it is clear that 32 of the scenarios did not achieve economies of scale. Furthermore, nine of the ten farm sizes are not scale efficient when using $100 \%$ of their capital needs; most of the farm sizes become scale inefficient when approximately more than $30 \%$ and less that $70 \%$ of their maximum capital needs are employed, the farm sizes of 400 hectares and smaller are fully scale efficient with lower levels of capital and the remaining larger farm sizes are only fully scale efficient with a moderate level of capital. This implies that the relatively smaller farms can easily achieve economies of scale with low levels of capital, while the relatively larger farms achieve economies of scale with moderate capital levels. From these findings, the study concludes that the financial success of establishing an SA Boer goat farm is locked up in the natural herd growth of animals. The practical implication is that aspirating SA Boer goat farmers will be the most efficient when the farm is not immediately stocked at the maximum level of animals, but to stock it only partly and to wait for the gain in herd growth. Furthermore, the open question was: How much capital should be employed for a given farm size?' A safe answer to the question would be to employ only approximately $50 \%((30 \%+70 \%) / 2)$ of the maximum capital needs.

This study contributes to the literature by proposing a model to determine optimal capital needs for financial success. Although the model was demonstrated in a case study in a specific region in South Africa, a similar model can be used everywhere to cater for unique circumstances such as bearing power and climate of a region. The importance of the contribution is by estimating technical efficiency, an answer is provided of how well the different combinations of farm sizes and capital employed are converted into eight different financial performance measures. Furthermore, inefficient scenarios are identified and targets can be estimated for these scenarios to become fully efficient. Regarding the importance of estimating scale efficiency, an answer is provided whether a scenario operates on a scale that maximizes productivity. Inefficient scenarios are identified with an indication of whether it is too small or too large in scale of operations. The value of the study is therefore that this is the first effort to build a DEA model to determine the efficiency to convert inputs into financial performance measures for an SA Boer goat farm. However, the limitations of the study are that the study data are based on a number of assumptions and always changing monetary values. The study also did not investigate intensive SA Boer goat farming, e.g. feeding-paddock farming. Finally, another limitation is that the study did not investigate a combination of SA Boer goats with other species such as sheep and cattle. Therefore, future studies can be done, firstly to verify the results of this study, secondly, to investigate the capital needs for intensive SA Boer goat farming and thirdly, where a combination of species are utilizing the same farm.

\section{AUTHOR INFORMATION}

Merwe Oberholzer $(\mathrm{PhD})$ is currently a professor in the School of Accounting Sciences at the North-West University, South Africa. He has taught extensively in the Chartered Accountancy and Chartered Management Accountancy programs. His academic research output includes more than 40 peer-reviewed articles and conference presentations. His current research focuses mainly on corporate resilience, sustainability, and DEA modeling. E-mail: Merwe.Oberholzer@nwu.ac.za 
Pieter W. Buys (PhD, CMA) is currently a professor and Research Program Leader at the School of Accounting Sciences at the North-West University, South Africa. He has taught extensively in the Chartered Management Accountancy programs and the MBA program. His academic research output includes more than 40 peer-reviewed articles and conference presentations. His current research focuses mainly on corporate governance and sustainability. E-mail: Pieter.Buys@nwu.ac.za (Corresponding author)

Wilbrie Fourie is currently the Financial Director at Tacktech (Pty) Ltd (South Africa). He has completed the TOPCIMA exam (from the Chartered Institute of Management Accountants in the UK) as best student in South Africa in 2009. This article is based on the research conducted for his M.Comm degree in Management accountancy at the School of Accounting Sciences, North-West University, South Africa.

\section{REFERENCES}

1. Acocks, J. P. H. (1988). Veld types of South Africa. In Botanical research institute: Memoirs of the botanical survey of South Africa. Pretoria.

2. Anderson, T. (1996). A data envelopment analysis (DEA) homepage. Retrieved from http://www.emp.pdx.edu.dea/homedea.html

3. Avkiran, N. (1999). Application reference for data envelopment analysis in branch banking: Helping the novice researcher. International Journal of Bank Marketing, 17(5), 206-220.

4. Boshoff, J. (2011). Oral communication with author on 8 February. Potchefstroom.

5. Botha, T. (1999). Boerbok het wêreld aan die gons [Boer goats get world buzzing]. Landbouweekblad, 1012, 10 September.

6. Buys, P. W., Oberholzer, M., \& Prinsloo, T. (2011). Estimating scale efficiency of platinum-mining companies' environmental performance: A South African perspective. International Business \& Economics Research Journal, 10(12), 11-22.

7. Casey, N. H., \& Van Niekerk, W. A. (1988). The boer goat (Part 1): Origin, adaptability, performance testing, reproduction and milk production. Small Ruminant Research, 1(3), 291-302.

8. Cilliers, J. (2011). Oral communication with author on 17 March. Potchefstroom.

9. Coelli, T., Rao, D. S. P., O'Donnell, C. J., \& Battese, G. E. (2005). An introduction to efficiency and productivity analysis $\left(2^{\text {nd }}\right.$ ed.). New York: Springer.

10. Correia, C., Flynn, D., Uliana, E., \& Wormald, M. (2010). Financial management ( $^{\text {th }}$ ed.). Cape Town: Juta.

11. De Chalain, F. (2010). Oral communication with author on 10 July. Potchefstroom.

12. Gouws, A. (2002). Boerbok kan man staan [Boer goat stands its man]. Landbouweekblad, 12-15, 3 May.

13. Hawawini, G., \& Viallet, C. (2011). Finance for executives: Managing for value creation ( $4^{\text {th }}$ ed.). Boston: South-Western College Publishers.

14. Landbouweekblad. (2013). Website. Retrieved from http://www.landbou.com/

15. Liu, S.T., \& Wang, R.-T. (2009). Efficiency measures of PCB manufacturing firms using rational two-stage data envelopment analysis. Expert Systems with Application, 36, 4935-4939.

16. Mahgoub, O., Kadim, I. T., \& Lu, C. D. (2012a). Overview of the global goat meat sector. In O. Mahgoub, I. T. Kadim, \& E. C. Webb (eds). Goat meat production and quality. Oxford Shire: CAB International.

17. Mahgoub, O., Kadim, I. T., \& Webb, E. C. (2012b). Preface. In O. Mahgoub, I. T. Kadim, \& E. C. Webb (eds). Goat meat production and quality. Oxford Shire: CAB International.

18. Malan, S. W. (2000). The improved Boer goat. Small Ruminant Research, 36(2), 165-170.

19. Mason, I. L. (1988). World dictionary of livestock breeds ( ${ }^{\text {rd }}$ ed.). Wallingford: CAB International.

20. Midgley, D. (2007). Meer parings sorg vir dividend [More mating earn dividends]. In Pfizer Animal Health Publications. Retrieved from http://www.pfizer.co.za/RunTime/ POPContent Run.aspx?pageidref=1975

21. Min, H., Min, H., Joo, S. J., \& Kim, J. (2009). Evaluating the financial performance of Korean luxury hotels using data envelopment analysis. The Service Industries Journal, 29(6), 835-845.

22. Mouton, J. (2011). Oral communication with author on 4 February. Potchefstroom.

23. Murthy, D. S., Sudha, M., Hegde, M. R., \& Dakshinamoothy, V. (2009). Technical efficiency and its determinants in tomato production in Karnataka, India: Data Envelopment (DEA) Approach. Agricultural Economics Research Review, 22, 215-224.

24. Naude, F. (2011). Oral communication with author on 8 February. Potchefstroom. 
25. Oberholzer, M. (2012). The relative importance of financial ratios in creating shareholders' wealth. South African Journal of Economic and Management Sciences, 15(4), 416-428.

26. Ray. S. C. (2004). Data envelopment analysis: Theory and techniques for economics and operational research. Cambridge: Cambridge University Press.

27. SA Boer Goat Breeders Association. (2011). Website. Retrieved from http://www.Boer goatsa.co.za/

28. Schoeman, S. J., Cloete, S. W. P., \& Olivier, J. J. (2010). Returns on investment in sheep and goat breeding in South Africa. Livestock Science, doi:10.1016/j.livsci.2010.02.012

29. Statistics South Africa, (2006). Survey of large scale agriculture. Retrieved from http://www.statssa.gov.za/PublicationsHTML/P110112006/html/P110112006_1.html?gInitialPosX=10px\& gInitialPos $Y=10 \mathrm{px} \& \mathrm{gZoomValue}=100$

30. Theunissen, M. (2012). An application of Data Envelopment Analysis to benchmark CEO remuneration. (MCom mini-dissertation). North-West University.

31. Van Zyl, A. (2011). Oral communication with author on 7 February. Potchefstroom.

32. Van Zyl, B. (2011). Oral communication with author on 7 February. Potchefstroom.

33. Zhu, J. (2009). Quantitative models for performance evaluation and benchmarking: Data envelopment with spreadsheets and DEA Excel Solver. New York: Springer. 


\section{APPENDIX}

\section{Various Technical Factors and Assumptions}

There are a number of technical factors that affect financial evaluations of the different types of farming. In order to conduct the study, assumptions have been made, and are discussed below:

- $\quad$ The goats graze in the field and sleep in a small camp during nights. During the lambing season, the ewes are placed in a lambing camp. Therefore, this study does not investigate feeding-paddock farming.

- $\quad$ Farm location: The farm is situated in the North West Province in the Potchefstroom area. In the North West Province, livestock farming is general and it is the province of South Africa with the fourth most livestock. There is adequate support such as markets, auctions, livestock experts, dosing products, and livestock handling facilities in this area (Statistics South Africa, 2006).

- $\quad$ Field type: It consists mainly of grassland with Karoo-like shrubs scattered and is described as Cymbopogon-Themeda Field (Acocks, 1988, p. 37).

- $\quad$ Farm size: For research purposes, it was assumed that all farms have a perfect square shape.

- $\quad$ Fencing: The cost of fencing includes only the physical supplies and not the labor. For the purpose of this study, the researcher has assumed that the farm is enclosed by a fence consisting of five strands of wire already. The recommended number of strands of wire for goats is ten strands of wire (Naude, 2011). The cost of single barbed fence is R0.56 per meter (Naude, 2011).

- Herd diversity: For the purpose of this study, the researcher has assumed that the herd consists of females, all being set for conception already and that they would be pregnant within one month from the beginning of the study. For the purpose of the study, they have assumed that there are enough male breeding animals, but that their small numbers are omissible.

- Herd growth: It has been assumed that the age of animals in the herd is evenly distributed from the age ready to produce up to tailings. The researcher has accepted that culling will be sold annually. The breeding size of the herd will be filled by offspring from the flock. The specie involved can produce offspring from one to ten years. The following rates are applicable to the determination of the percentage of the herd that will be sold as waste annually: 11 percent (Mouton, 2011; Van Zyl, B., 2011; Van Zyl, A., 2011).

- $\quad$ Breeding rate per year: 120 percent (Van Zyl A. 2011; Boshoff, 2011).

- $\quad$ Selling prices: As there is no formal market indicator for the price of Boer goat the opinion of experts has been used (Van Zyl, A., 2011; Boshoff, 2011): Gelded Boer goat, R26 per kilogram (on the hoof); and culling, R32 per kilogram.

- $\quad$ Purchase price: The purchase price of females is as follows (Mouton, 2011; Van Zyl, B., 2011; Van Zyl, A., 2011; Boshoff, 2011): R1500 per unit.

- Weight: According to Van Zyl, A. (2011) and Boshoff (2011), the details regarding goats are as follows: Weaning weight (on the hoof) 30 kilograms and culling weight (carcass) 23 kilograms.

- $\quad$ Bearing power: The bearing power in this area is as follows (Mouton, 2011; Van Zyl, B., 2011; Van Zyl, A., 2011; Boshoff, 2011): 0.86 hectare per unit.

- Labor: Although the labor intensity of the different farming industries differs, there is not a constant amount of labor for each farm as farmers' views of labor needs differ. For purposes of the study, the following amount per unit per year was used: R57.60 (Mouton, 2011; Van Zyl, B., 2011).

- Capital: The capital available is sufficient to set up the farm for the keeping and handling of the animals, as well as to purchase the initial herd.

- $\quad$ Stock handling facilities: Since there are various factors that play a role in setting up stock handling facilities (e.g. crush-pens), it has been decided to use an average amount for the farm sizes: R37,937 (De Chalain, 2010).

- $\quad$ Dosing: It has been determined for the different farming industries in the area based on Cilliers (2011), in consultation with the management program of SENWES Potchefstroom. A list of dosing medicines and dosing periods was compiled and the cost per female breeding animal calculated accordingly: R70.55.

- Mineral supplements per year: The authors mentioned have determined it as follows: R163.11 (Mouton, 2011; Van Zyl, B., 2011). 